\title{
Kajian patogenisitas bakteri Edwardsiella ictaluri pada ikan patin Pangasionodon hypophthalmus
}

\section{Pathogenicity of Edwardsiella ictaluri infection in striped catfish Pangasionodon hypophthalmus}

\author{
Wiwik Susanti ${ }^{1}$, Agustin Indrawati ${ }^{2}$, Fachriyan H Pasaribu ${ }^{2 *}$ \\ ${ }^{1}$ Balai Perikanan Budidaya Air Tawar Mandiangin Kalimantan Selatan, Kementerian Kelautan dan Perikanan \\ Jalan Tahura Sultan Adam, Mandiangin, Kalimantan Selatan 70761 \\ ${ }^{2}$ Program Studi Mikrobiologi Medik, Fakultas Kedokteran Hewan, Institut Pertanian Bogor \\ Kampus IPB Dramaga Bogor, Jawa Barat 16680 \\ *Surel: fhpasaribu@gmail.com
}

\begin{abstract}
One of major problem of striped catfish Pangasionodon hypophthalmus culture is enteric septicemia of catfish (ESC), bacterial disease of Edwardsiella ictaluri, caused of more than 50\% of mortalities. This reaserch was aimed to determine pathogenicity of local isolate E. ictaluri. Thirty individu of five group fishes, $6-10 \mathrm{~g}$ in body weight, injected intraperitoneally with $0,1 \mathrm{~mL}$ of bacteria suspension of $10^{2} \mathrm{cfu} / \mathrm{mL} ; 10^{4} \mathrm{cfu} / \mathrm{mL} ; 10^{6} \mathrm{cfu} / \mathrm{mL} ; 10^{8}$ $\mathrm{cfu} / \mathrm{mL} ; 10^{10} \mathrm{cfu} / \mathrm{mL}$; and PBS as control, were culture in 18 of $60 \times 40 \times 45 \mathrm{~cm}^{3}$ aquarium for seven days. External organs of fish (skin and abdomen) and internal organs (liver, kidney, and brain) were examined macroscopicly and microscopicly. Internal organ sample were taken on the $5^{\text {th }}$ day for histopatologic test while blood sample was on the $1^{\text {st }}, 3^{\text {rd }}$, and $5^{\text {th }}$ day after infection. Mortality rate was count to reach LD50. Clinical signs and pathology anatomy of co-infection fish showed vertical swim, petechial hemorrhage in the skin, dropsy, ascites in the abdominal cavity, pale liver and the kidney was dark red. Histopathology showed hydropic degeneration, fatty degeneration, hemorrhage and necrosis in the liver, melano macrophage center (MMC) and necrosis in the kidneys, hemorrhage, and inflammatory cell infiltrates were also found in the kidneys and brain. Decreased of hematocrit and hemoglobin values of all tread group were statistically significant different $(\mathrm{P}<0,05)$ compared to controls. LD50 dose was $2,8 \times 10^{4} \mathrm{cfu} / \mathrm{mL}$. The result indicated that E. ictaluri was very pathogenic on striped catfish $P$. hypophthalmus.
\end{abstract}

Keywords: Edwardsiella ictaluri, enteric septicemia of catfish (ESC), pathogenicity, striped catfish

\begin{abstract}
ABSTRAK
Salah satu kendala yang dijumpai pada budidaya ikan patin Pangasionodon hypophthalmus yaitu serangan penyakit bakterial. Enteric septicemia of catfish (ESC) adalah penyakit infeksi bakteri Edwardsiella ictaluri yang dapat menyebabkan kematian ikan patin sampai $>50 \%$. Penelitian ini dilakukan untuk mengetahui patogenisitas E. ictaluri isolat lokal pada ikan patin. Masing-masing 30 ekor ikan patin ukuran 6-10 g/ekor diinjeksi secara intraperitoneal dengan $0,1 \mathrm{~mL}$ larutan bakteri kepadatan $10^{2} \mathrm{cfu} / \mathrm{mL} ; 10^{4} \mathrm{cfu} / \mathrm{mL} ; 10^{6} \mathrm{cfu} / \mathrm{mL} ; 10^{8} \mathrm{cfu} / \mathrm{mL} ; 10^{10}$ cfu/mL; dan PBS sebagai kontrol. Ikan dipelihara selama tujuh hari pada akuarium berukuran $60 \times 40 \times 45 \mathrm{~cm}^{3}$. Pemeriksaan makroskopis dan mikroskopis dilakukan terhadap organ eksternal (kulit dan abdomen) dan internal (hati, ginjal, dan otak). Pengambilan sampel organ internal untuk uji histopatologi pada hari kelima dan sampel darah untuk uji gambaran darah pada hari pertama, ketiga, dan kelima pascainfeksi. Jumlah kematian ikan dihitung untuk mendapat nilai LD50. Pengamatan gejala klinis dan patologi anatomi ditemukan ikan berenang vertikal, adanya bercak merah pada kulit, pembengkakan abdomen, asites, hati pucat, dan ginjal berwarna merah kehitaman. Hasil histopatologi terlihat terjadinya degenerasi hidropik, degenerasi lemak, melano macrophage center (MMC), nekrosa, hemoragi, dan infiltrasi sel radang pada hati, ginjal, dan otak. Penurunan nilai hematokrit dan hemoglobin pada perlakuan secara statistik berbeda nyata $(\mathrm{P}<0,05)$ dengan kontrol. Dosis LD50 didapat $2,8 \times 10^{4} \mathrm{cfu} / \mathrm{mL}$. Hasil penelitian ini mengindikasikan bahwa E. ictaluri pada ikan patin bersifat sangat patogen.
\end{abstract}

Kata kunci: Edwardsiella ictaluri, enteric septicemia of catfish (ESC), patogenisitas, patin 


\section{PENDAHULUAN}

Ikan patin Pangasionodon hypophthalmus merupakan spesies ikan air tawar dari jenis Pangasidae yang dapat diproduksi secara masal dan memiliki peluang pengembangan skala industri. Ikan ini menjadi salah satu komoditas perikanan yang mempunyai nilai ekonomis tinggi, baik dalam segmen usaha perbenihan maupun usaha pembesarannya (Susanto, 2009). Propinsi Kalimantan Selatan dan Kalimantan Tengah telah ditetapkan menjadi kawasan minapolitan berdasarkan SK Menteri Kelautan dan Perikanan RI nomor 35/KEPMEN-KP/2013, ada delapan kabupaten ditunjuk sebagai sentra perikanan budidaya dan ikan patin merupakan salah satu komoditas unggulannya. Hal ini menjadikan pemerintah terus mendorong agar kedua propinsi ini mengembangkan budidaya ikan patin sehingga dapat mendukung produksi ikan patin nasional. Namun keberhasilan pengembangan budidaya ikan patin ini tidak terlepas dari berbagai permasalahan budidaya salah satunya adanya serangan penyakit bakterial seperti penyakit enteric septicemia of catfish (ESC).

Edwarsiella ictaluri merupakan bakteri penyebab terjadinya penyakit bakterial sistemik ESC. Penyakit ini awalnya diketahui hanya menginfeksi ikan Channel catfish Ictalurus punctatus, namun kemudian dapat menginfeksi jenis catfish lainnya seperti ikan lele, patin, dan sidat. Spesies selain catfish yang dilaporkan dapat terinfeksi $E$. ictaluri yaitu ikan nila Oreochromis niloticus (Soto et al., 2012) dan ikan ayu Plecoglossus altivelis (Nagai et al., 2008; Sakai et al., 2008). Secara eksperimental ikan white perch Morone americana, chinook salmon Oncorhynchus tshawytscha, dan rainbow trout O. mykiss (Pasnik et al., 2007) serta zebrafish Danio rerio (Petrie-Hanson et al., 2007) juga dapat terinfeksi oleh bakteri ini. Masing-masing ikan mempunyai kerentanan yang berbeda terhadap infeksi E. ictaluri. Ikan nila dapat mengalami kematian sampai $40 \%$ pada infeksi bakteri dengan konsentrasi $10^{3} \mathrm{cfu} / \mathrm{mL}$ (Soto et al., 2012). Konsentrasi E. ictaluri $10^{4} \mathrm{cfu} / \mathrm{mL}$ dapat menginfeksi ikan ayu dan menimbulkan kematian sampai 50\% (Sakai et al., 2008). Selain itu Suanyuk et al. (2014) melaporkan bahwa konsentrasi E. ictaluri $10^{6} \mathrm{cfu} / \mathrm{mL}$ menimbulkan kematian 50\% ikan lele hibrid dan menurut laporan Pasnik et al. (2007) bahwa kematian ikan white perch terjadi sampai $100 \%$ pada infeksi $E$. ictaluri $10^{7} \mathrm{cfu} / \mathrm{mL}$.
Awal kemunculannya di daerah Mississipi penyakit ESC dapat menyebabkan kematian sampai $47 \%$ dari total produksi setahun ikan Channel catfish dan mengakibatkan kerugian ekonomi dalam jutaan dollar. E. ictaluri menjadi salah satu patogen penting yang berpengaruh pada budidaya ikan Channel catfish (Shoemaker et al., 2009). E. ictaluri pertama kali ditemukan di Indonesia tahun 2002 (Sakai et al., 2009), menginfeksi patin siam di wilayah Jambi juga menimbulkan kerugian ekonomi yang tidak sedikit. Di Kalimantan Selatan dan Kalimantan Tengah juga telah dilaporkan mulai tahun 2012 bahwa penyakit ini telah menyerang budidaya ikan patin $P$. hypophthalmus dan menyebabkan kematian sampai $>50 \%$ (BBAT Mandiangin, 2013). Oleh karena itu dapat dikatakan ESC sebagai penyakit penting dan berpengaruh dalam perikanan budidaya.

Sampai saat ini patogenisitas E. ictaluri isolat lokal yang menyerang ikan patin belum sepenuhnya diketahui, oleh karena itu perlu dilakukan penelitian untuk mengungkapkan informasi yang lebih mendalam tentang $E$. ictaluri. Informasi tersebut antara lain tentang histopatologi organ hati, ginjal, dan otak serta hematologi (hematokrit dan hemoglobin) pada ikan patin yang terinfeksi $E$. ictaluri. Informasi ini selanjutnya tidak hanya berguna untuk diagnosis penyakit bakteri ESC tetapi juga sebagai upaya dalam rangka pencegahan terhadap serangan patogen ini.

\section{BAHAN DAN METODE}

\section{Ikan uji}

Ikan uji yang digunakan adalah ikan patin $P$. hypophthalmus berukuran 6-10 g/ekor. Sebelum dilakukan pengujian, ikan diaklimatisasi terlebih dahulu selama 14 hari. Selama masa karantina ikan uji tidak menunjukkan gejala terinfeksi ESC berdasarkan diagnosis dan pengujian mikrobiologi. Pengujian secara mikrobiologi dilakukan terhadap sampel organ ginjal, hati, dan otak yang diambil secara acak.

\section{Bakteri uji}

Bakteri yang digunakan adalah E. ictaluri (isolat IP.BK.02) merupakan koleksi Balai Perikanan Budidaya Air Tawar (BPBAT) Mandiangin Kalimantan Selatan Kementerian Kelautan dan Perikanan. Pengujian Postulat Koch dilakukan untuk mengembalikan virulensi bakteri sebelum digunakan untuk perlakuan 
dalam penelitian. E. ictaluri (isolat IP.BK.02) dibiakan pada media cair brain heart infusion broth (BHIB) dan diinkubasi pada suhu 25-28 ${ }^{\circ} \mathrm{C}$ selama 24-48 jam (Koswara, 2009; Thinh et al., 2009). Panen bakteri dilakukan dengan cara sentrifugasi pada $3.500 \mathrm{rpm}$ selama 20 menit. Setelah supernatan dibuang kemudian ditambah pelarut phosphate buffer saline (PBS) dan diaduk dengan vortex hingga homogen, setelah itu dilakukan penghitungan kekeruhan suspensi bakteri. Biakan E. ictaluri konsentrasi $10^{9} \mathrm{cfu} / \mathrm{mL}$ sebanyak $0,1 \mathrm{~mL}$ disuntikkan secara intraperitoneal pada ikan uji. Setelah $2-3$ hari masa inkubasi, ikan yang menunjukkan gejala penyakit ESC segera dikeluarkan dari kelompoknya. Isolasi bakteri dilakukan dari organ ginjal dan hati pada media selektif $E$. ictaluri medium (EIM, Shotts dan Waltman) dan media brain heart infusion agar (BHIA) untuk mendapat isolat murni, setelah bakteri tumbuh dilakukan pemeriksaan sifat-sifat biokimianya. Isolat bakteri yang telah virulen digunakan untuk uji selanjutnya.

\section{Uji patogenisitas E. ictaluri}

Uji patogenisitas E. ictaluri menggunakan lima perlakuan dengan kepadatan bakteri yang digunakan yaitu $10^{2} \mathrm{cfu} / \mathrm{mL} ; 10^{4} \mathrm{cfu} / \mathrm{mL} ; 10^{6} \mathrm{cfu} /$ $\mathrm{mL} ; 10^{8} \mathrm{cfu} / \mathrm{mL} ; 10^{10} \mathrm{cfu} / \mathrm{mL}$; dan satu kontrol dengan PBS. Injeksi dilakukan pada 30 ekor ikan uji tiap perlakuan secara intraperitoneal $0,1 \mathrm{~mL} / \mathrm{ekor}$ ikan. Ikan dipelihara selama tujuh hari pada akuarium berukuran $60 \times 40 \times 45 \mathrm{~cm}^{3}$. Pakan komersial kandungan protein $32-34 \%$ dan kadar lemak 6\% diberikan dua kali sehari selama pemeliharaan.

Pengamatan gejala klinis dan patologi anatomi dilakukan untuk mengamati perubahan patologi organ eksternal dan internal ikan patin. Pengamatan mikroskopis dengan uji histopatologi (HP) dilakukan pada organ ginjal, hati, dan otak. Pengambilan sampel untuk uji histopatologi diambil pada hari kelima pascainfeksi. Pewarnaan preparat uji HP menggunakan pewarnaan haematoxillin dan eosin (HE). Pengambilan sampel untuk uji gambaran darah dilakukan hari pertama, ketiga, dan kelima pascainjeksi bakteri, parameter yang diamati yaitu hematokrit dan hemoglobin. Hematokrit diukur dengan menggunakan tabung kapiler berlapis heparin kemudian disentrifugasi pada $12.000 \mathrm{rpm}$ selama lima menit sedangkan hemoglobin menggunakan metode Sahli (Docan et al., 2010). Jumlah kematian ikan dihitung untuk mendapat nilai LD50. Penghitungan nilai LD50 dilakukan menggunakan metode Reed dan Muench (Saganuwan, 2011).

\section{Pengukuran kualitas air}

Pengukuran kualitas air dilakukan setiap tiga hari sekali. Suhu dan oksigen terlarut (dissolved oxygen, DO) diukur secara in situ menggunakan alat DO meter, $\mathrm{pH}$ diukur secara in situ menggunakan alat $\mathrm{pH}$ meter. Kisaran kualitas air selama penelitian menunjukan suhu 28,1-29,9 ${ }^{\circ} \mathrm{C}$; $\mathrm{pH}$ air 6,52-7,1; dan oksigen terlarut 2,594,24 mg/L. Nilai kisaran ini masih sesuai dengan prosedur budidaya ikan patin (Hekimoglu et al., 2014).

\section{Analisis data}

Data kuantitatif pengamatan hemoglobin, hematokrit ditabulasi menggunakan alat bantu program Microsoft Excel 2007 dan dianalisis secara statistik menggunakan software Minitab 14, lalu diuji normalitasnya. Uji Tukey dilakukan pada taraf 95\%. Jumlah kematian ikan, nilai LD50 dan perubahan makroskopis maupun mikroskopis organ ikan dianalisis secara deskriptif.

\section{HASIL DAN PEMBAHASAN}

E. ictaluri dapat menginfeksi inangnya secara akut, subakut, dan kronis (Cunningham et al., 2014). Hawke et al. 2013 melaporkan bahwa pada bentuk infeksi kronis, setelah bakteri menginfeksi kantung olfaktorius selanjutnya menyebar ke sepanjang saraf olfaktorius menuju otak, menyebabkan meningoenchephalitis. Infeksi $E$. ictaluri secara akut diduga melalui mukosa usus dan menyebabkan bakteremia. Kedua bentuk serangan penyakit ESC ini dapat menimbulkan tingkat keparahan yang tinggi dan menyebabkan kematian ikan lebih dari $>50 \%$.

\section{Pengamatan makroskopis dan mikroskopis organ ikan patin uji}

Hasil penelitian menunjukan setelah ikan patin diinfeksi secara intraperitoneal dengan konsentrasi E. ictaluri berbeda, dari konsentrasi $10^{4} \mathrm{cfu} / \mathrm{mL}$ sampai dengan $10^{10} \mathrm{cfu} / \mathrm{mL}$ menimbulkan gejala klinis antara lain: timbulnya bercak merah pada kulit, pembengkakan abdomen, dan ikan berenang dengan kepala di permukaan air/vertikal, namun ikan patin uji yang diinfeksi dengan konsentrasi bakteri $10^{2}$ $\mathrm{cfu} / \mathrm{mL}$ tidak terlihat ada perubahan (Tabel 1 dan Gambar 1). 
Sakai et al. (2008) menyatakan bahwa beberapa tanda klinis pada penyakit ESC adalah adanya bercak merah pada kulit dibawah rahang, operkulum, disekitar perut, dan anus serta bagian bawah sirip. Terjadinya pembengkakan abdomen dan organ dalam seperti hati, ginjal, dan limpa serta sebelum mati ikan berenang menggantung hampir vertikal dengan kepala di permukaan air (Kim \& Park, 2015).

Perubahan patologi anatomi pada ikan uji yang terinfeksi E. ictaluri mulai teramati pada konsentrasi bakteri $10^{4} \mathrm{cfu} / \mathrm{mL}$ yaitu adanya kerusakan organ dalam (Tabel 2 dan Gambar 2) antara lain hati pucat dan membesar, ginjal

Tabel 1. Gejala klinis ikan patin setelah infeksi E. ictaluri

\begin{tabular}{cccc}
\hline \multirow{2}{*}{$\begin{array}{c}\text { Konsentrasi bakteri } \\
(\mathrm{cfu} / \mathrm{mL}) \text { per ikan }\end{array}$} & Kulit & Abdomen & Gerakan renang \\
\cline { 2 - 4 } & TAP & TAP & TAP \\
\hline Kontrol & TAP & TAP & TAP \\
$10^{2}$ & bercak merah & ukuran membesar & gerak renang vertikal \\
$10^{4}$ & bercak merah & ukuran membesar & gerak renang vertikal \\
$10^{6}$ & bercak merah & ukuran membesar & gerak renang vertikal \\
$10^{8}$ & bercak merah & ukuran membesar & gerak renang vertikal \\
\hline $10^{10}$ & & & \\
\hline
\end{tabular}

Keterangan: TAP = tidak ada perubahan.
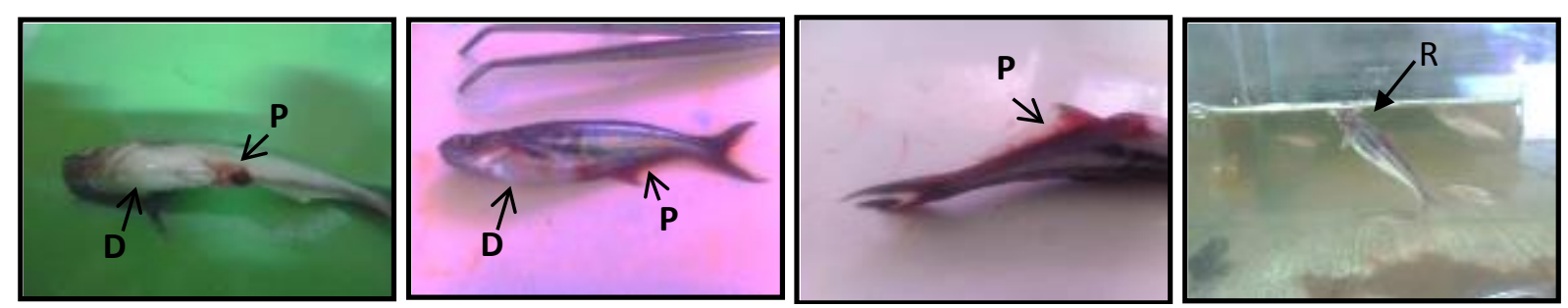

Gambar 1. Gejala klinis ikan patin sesudah diinfeksi E. ictaluri. (P) ptekhie hemoragi; bercak merah; (D) dropsy; perut membengkak; $(\mathrm{R})$ renang menggantung di permukaan air

Tabel 1. Gejala klinis ikan patin setelah infeksi E. ictaluri

\begin{tabular}{|c|c|c|c|c|}
\hline \multirow{3}{*}{$\begin{array}{c}\text { Konsentrasi } \\
\text { bakteri }(\mathrm{cfu} / \mathrm{mL}) \\
\text { per ikan }\end{array}$} & \multicolumn{4}{|c|}{ Patologi anatomi } \\
\hline & \multirow{2}{*}{$\begin{array}{c}\text { Asites } \\
\text { TAP }\end{array}$} & \multicolumn{2}{|c|}{ Hati } & \multirow{2}{*}{$\begin{array}{c}\text { Ginjal } \\
\text { TAP }\end{array}$} \\
\hline & & TAP & TAP & \\
\hline $10^{2}$ & TAP & TAP & TAP & TAP \\
\hline $10^{4}$ & ada & ukuran membesar & warna pucat & warna merah kehitaman \\
\hline $10^{6}$ & ada & ukuran membesar & warna pucat & warna merah kehitaman \\
\hline $10^{8}$ & ada & ukuran membesar & warna pucat & warna merah kehitaman \\
\hline $10^{10}$ & ada & ukuran membesar & warna pucat & warna merah kehitaman \\
\hline
\end{tabular}

Keterangan: TAP $=$ tidak ada perubahan.
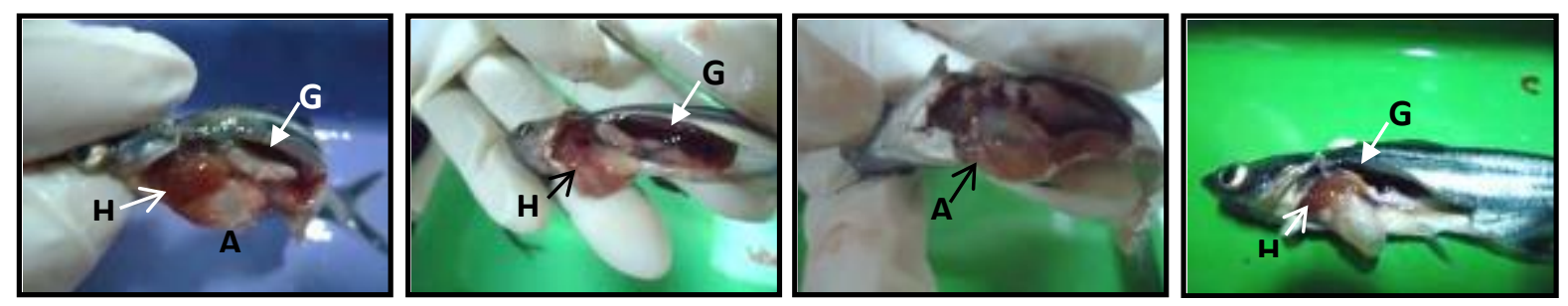

Gambar 2. Patologi anatomi organ dalam ikan patin sesudah diinfeksi E. ictaluri. (A) ascites (timbunan cairan); $(\mathrm{H})$ hati membesar dan berwarna pucat; $(\mathrm{G})$ ginjal berwarna merah kehitaman. 
menjadi merah kehitaman, adanya asites, atau timbunan cairan yang berwarna kuning keruh, atau bening, atau dapat juga cairan darah. Hati yang membesar dan adanya asites mengakibatkan pembengkakan abdomen. Seperti dilaporkan oleh Hassan et al. (2012) bahwa ditemukan adanya asites pada ikan yang mati karena infeksi E. ictaluri.
Pengamatan histopatologi menunjukkan adanya kerusakan jaringan akibat infeksi E. ictaluri, pada organ hati ditandai adanya degenerasi hidropik, dan degenerasi lemak, sedangkan ginjal terdapat melano macrophage center (MMC), dan infiltrasi sel radang demikian juga pada otak terjadi infiltrasi sel radang. Terjadinya hemoragi dan nekrosis juga ditemukan

Tabel 1. Gejala klinis ikan patin setelah infeksi E. ictaluri

\begin{tabular}{|c|c|c|c|c|c|c|c|c|c|c|c|}
\hline \multirow{2}{*}{$\begin{array}{c}\text { Konsentrasi } \\
\text { bakteri }(\mathrm{cfu} / \mathrm{mL}) \\
\text { per ikan }\end{array}$} & \multicolumn{4}{|c|}{ Hati } & \multicolumn{4}{|c|}{ Ginjal } & \multicolumn{3}{|c|}{ Otak } \\
\hline & $\mathrm{DH}$ & DL & $\mathrm{H}$ & $\mathrm{N}$ & MMC & $\mathrm{R}$ & $\mathrm{H}$ & $\mathrm{N}$ & $\mathrm{R}$ & $\mathrm{H}$ & $\mathrm{N}$ \\
\hline Kontrol & - & - & - & - & - & - & - & - & - & - & - \\
\hline $10^{2}$ & - & - & + & - & - & + & - & - & - & - & - \\
\hline $10^{4}$ & + & + & + & + & + & + & + & + & + & + & + \\
\hline $10^{6}$ & + & + & + & + & + & + & + & + & + & + & + \\
\hline $10^{8}$ & + & + & + & + & + & + & + & + & + & + & + \\
\hline $10^{10}$ & + & + & + & + & + & + & + & + & + & + & + \\
\hline
\end{tabular}

Keterangan: $\mathrm{DH}=$ degenerasi hidropik, $\mathrm{DL}=$ degenerasi lemak, $\mathrm{H}=$ hemoragi, $\mathrm{N}=$ nekrosis, $\mathrm{MMC}=$ melano makrofag center, $\mathrm{R}=$ sel radang.

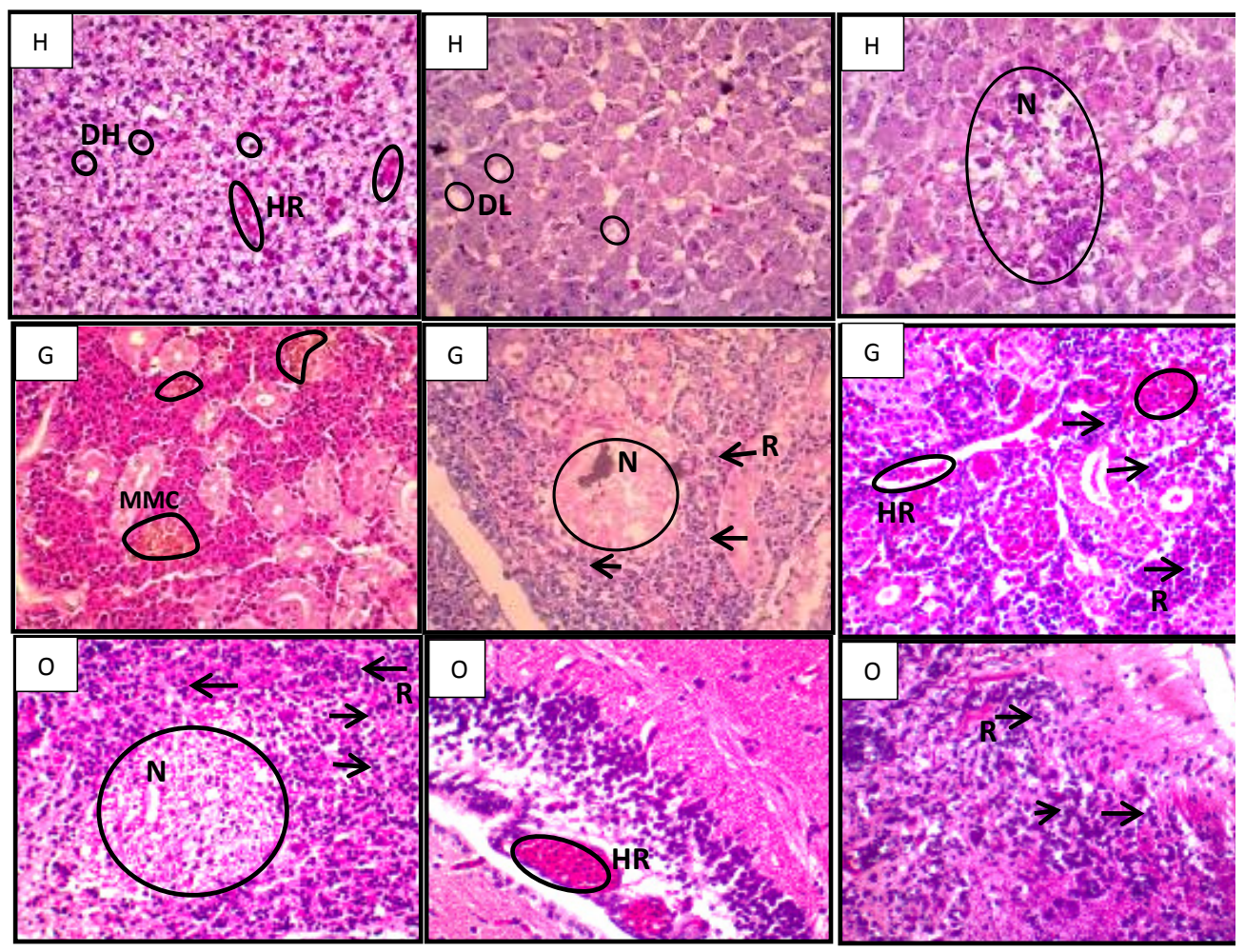

Gambar 3. Histopatologi organ hati $(\mathrm{H})$, ginjal $(\mathrm{G})$ dan otak $(\mathrm{O})$ ikan patin sesudah diinfeksi E. ictaluri. (DH) degenerasi hidropik; (DL) degenerasi lemak; (HR) hemoragi; (N) nekrosis; (MMC) melano macrophage center; (R) sel radang. (perbesaran 400 kali). 
pada ketiga organ tersebut (Tabel 3 dan Gambar 3). Gambaran histopatologi tersebut sesuai dengan hasil pengamatan oleh Iwanowicz et al. (2006) pada ikan brown bullheads yang terinfeksi E. ictaluri yaitu adanya lesio pada organ internal dan eksternal (hati, usus, ginjal, dan kulit). Hawke et al. (2013) menemukan adanya nekrosis jaringan dan infiltrasi sel radang pada ginjal zebrafish Danio rerio yang terinfeksi E. ictaluri.

Fenomena degenerasi hidropik pada hati ikan patin setelah infeksi bakteri dalam penelitian ini mengindikasikan adanya respons awal sel terhadap bahan-bahan yang bersifat toksik, dan kerusakan sel karena adanya toksin yang masuk melalui membran sel sehingga mengakibatkan menurunnya produksi ATP dan terganggunya pengaturan ion sodium-potasium (Cheville, 2006). Sementara itu Williams dan Lawrence (2005) dalam penelitiannya melaporkan bahwa E. ictaluri dapat menghasilkan hemolisin dengan tipe $\beta$-hemolysis yang merupakan salah satu faktor virulensi bakteri tersebut. Hemolisin merupakan enzim ekstraseluler yang bersifat toksik, sehingga diduga enzim ini ikut berperan dalam kerusakan sel hati ikan patin setelah terinfeksi E. ictaluri. Degenerasi lemak menggambarkan adanya akumulasi lemak dalam sel yang terjadi karena terlalu banyak asupan asam lemak bebas ke dalam sel hati. Degenerasi lemak pada ikan yang terinfeksi $E$. ictaluri diduga akibat toksin yang merusak jalur metabolisme lemak dan akibat hipoksia yang terjadi karena melambatnya aliran darah sebagai respons terhadap adanya antigen dalam jaringan (Koswara, 2009).

Kelainan pada ginjal merupakan efek lanjutan dari degenerasi hati, yang dicirikan dengan adanya MMC, yaitu berupa agregat makrofag yang merupakan kumpulan sel yang mengandung pigmen pada jaringan. Proliferasi MMC merupakan indikasi adanya reaksi pertahanan tubuh pada ikan karena adanya bakteri yang menginfeksi (Kumaran et al., 2010). Infiltrasi sel radang juga ditemukan pada jaringan organ ginjal dan otak yang mengindikasikan terjadinya peradangan pada jaringan tersebut. Adanya hemoragi dapat disebabkan oleh kerusakan endotel kapiler akibat agen infeksi yang beredar di pembuluh darah, ini membuktikan bahwa E. ictaluri bersifat septicemia yang merusak pembuluh darah sehingga terjadi pendarahan. Booth et al. (2006) menyatakan bahwa ikan akan mengalami bakteremia 24 jam setelah terinfeksi E. ictaluri.

Lesio pada otak juga menandakan adanya infeksi E. ictaluri seperti dilaporkan Koswara (2009), ensefalitis merupakan salah satu lesio spesifik dari infeksi E. ictaluri. Kerusakan jaringan pada otak ini mengakibatkan terganggunya kontrol pergerakan dan keseimbangan ikan dalam berenang, sehingga terjadi perubahan perilaku gerakan renang ikan menjadi tidak normal (gerak renang vertikal).

\section{Parameter darah}

Selain gejala klinis dan patologi anatomi, parameter darah juga dapat menjadi indikator untuk melihat adanya perubahan kesehatan pada ikan. Hematokrit digunakan untuk melihat kondisi fisiologis dan indikator stres pada ikan. Hasil uji statistik terhadap persentase hematokrit pada ikan patin setelah diinjeksi E. ictaluri dengan berbagai konsentrasi yang berbeda menunjukkan perbedaan yang signifikan $(\mathrm{P}<0,05)$ terhadap kontrol. Penurunan kadar hematokrit mulai terjadi satu hari pascainfeksi dan nilai hematokrit ikan uji yang terendah $(7,3 \pm 1,15 \%)$ terjadi hari

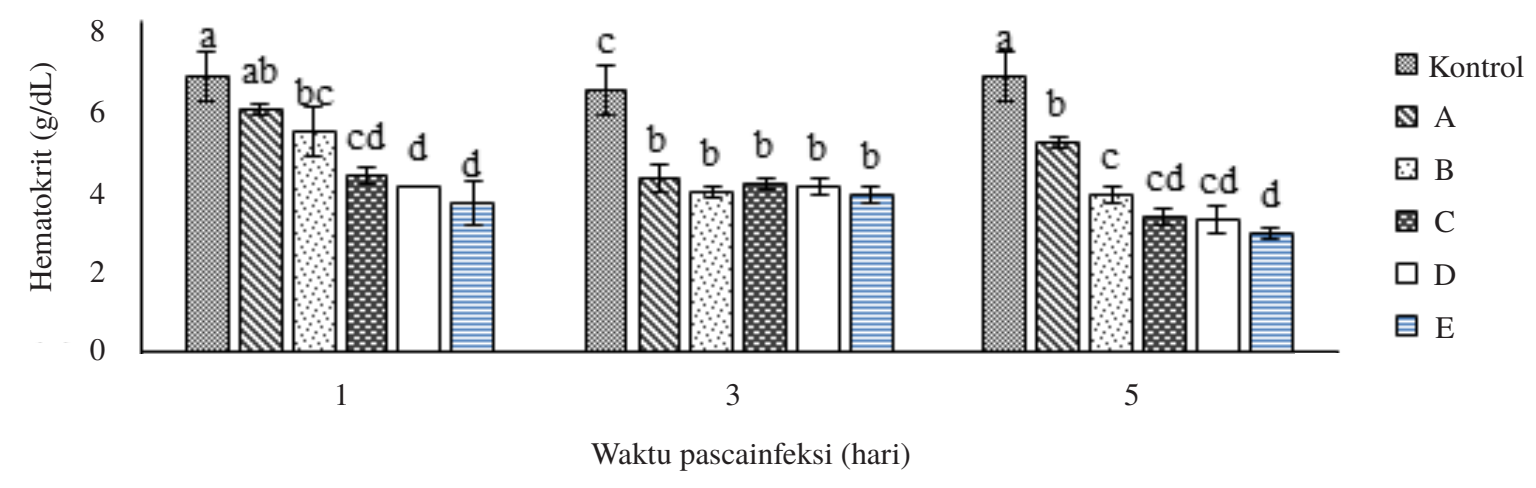

Gambar 4. Persentase hematokrit dalam darah ikan patin pascainfeksi E. ictaluri dengan konsentrasi berbeda. Kontrol, (A) konsentrasi $10^{2} \mathrm{cfu} / \mathrm{mL}$, (B) konsentrasi $10^{4} \mathrm{cfu} / \mathrm{mL}$, (C) konsentrasi $10^{6} \mathrm{cfu} / \mathrm{mL}$, (D) konsentrasi $10^{8}$ $\mathrm{cfu} / \mathrm{mL}$, (E) konsentrasi $10^{10} \mathrm{cfu} / \mathrm{mL}$. Huruf yang berbeda menunjukkan nilai berbeda nyata $(\mathrm{P}<0,05)$. 
kelima pascainfeksi pada konsentrasi bakteri $10^{8}$ $\mathrm{cfu} / \mathrm{mL}$ dan $10^{10} \mathrm{cfu} / \mathrm{mL}$ (Gambar 4).

Kadar hemoglobin pada semua perlakuan ikan patin yang diinfeksi E. ictaluri mengalami penurunan dengan nilai berkisar 2,9-5,3 g/ dL. Hampir semua nilai hemoglobin ikan patin pascainfeksi berbeda nyata $(\mathrm{P}<0,05)$ terhadap kontrol (Gambar 5), kecuali pada pengambilan sampel hari pertama pascainfeksi pada konsentrasi bakteri $10^{2} \mathrm{cfu} / \mathrm{mL}$ penurunan kadar hemoglobin tidak berbeda nyata dengan kontrol.

Penurunan nilai hematokrit dan hemoglobin pada ikan patin mengindikasikan bahwa ikan mengalami stres dan anemia akibat infeksi E. ictaluri. E. ictaluri menghasilkan toksin berupa hemolisin yang dapat menghancurkan sel darah merah (eritrosit), karena eritrosit lisis menyebabkan penurunan nilai hemoglobin. Antara nilai hematokrit dan jumlah hemoglobin darah mempunyai keterkaitan, semakin rendah jumlah sel darah merah akan semakin rendah pula kandungan hemoglobin dalam darah. Sesuai dengan hasil penelitian Shoemaker et al. (2012) bahwa ikan yang terinfeksi E. ictaluri akan mengalami anemia.

\section{Jumlah kematian kumulatif dan hasil LD50}

Munculnya gejala klinis, patologi anatomi, dan perubahan gambaran darah pada ikan patin uji disertai dengan terjadinya kematian ikan. Kematian ikan dimulai hari kedua pascainfeksi terutama pada konsentrasi bakteri $10^{8} \mathrm{cfu} / \mathrm{mL}$ dan $10^{10} \mathrm{cfu} / \mathrm{mL}$, sedangkan pada konsentrasi lebih rendah yaitu $10^{6}, 10^{4}$, dan $10^{2} \mathrm{cfu} / \mathrm{mL}$ kematian ikan dimulai hari ketiga (Tabel 4). Berdasarkan pola kematian yang cepat tersebut serangan enteric septicemia pada ikan patin bersifat akut. Konsentrasi bakteri $10^{8} \mathrm{cfu} / \mathrm{mL}$ dan $10^{10} \mathrm{cfu} / \mathrm{mL}$ merupakan konsentrasi yang paling mematikan bagi ikan patin karena pada dua konsentrasi tersebut menimbulkan kematian yang cepat dan mortalitas mencapai $100 \%$.

Data kematian ikan pada Tabel 5 selanjutnya digunakan untuk menghitung nilai LD50 dengan metode Reed dan Muench. Perhitungan LD50 menunjukkan bahwa kepadatan E. ictaluri yang menyebabkan kematian 50\% (LD50) ikan patin yaitu $2,8 \times 10^{4} \mathrm{cfu} / \mathrm{mL}$. Seperti yang disebutkan Sakai et al. (2008) bahwa LD50 E. ictaluri strain yang virulen pada ikan Channel catfish adalah $10^{3}-10^{5} \mathrm{cfu} / \mathrm{mL}$. Begitu juga hasil pengamatan

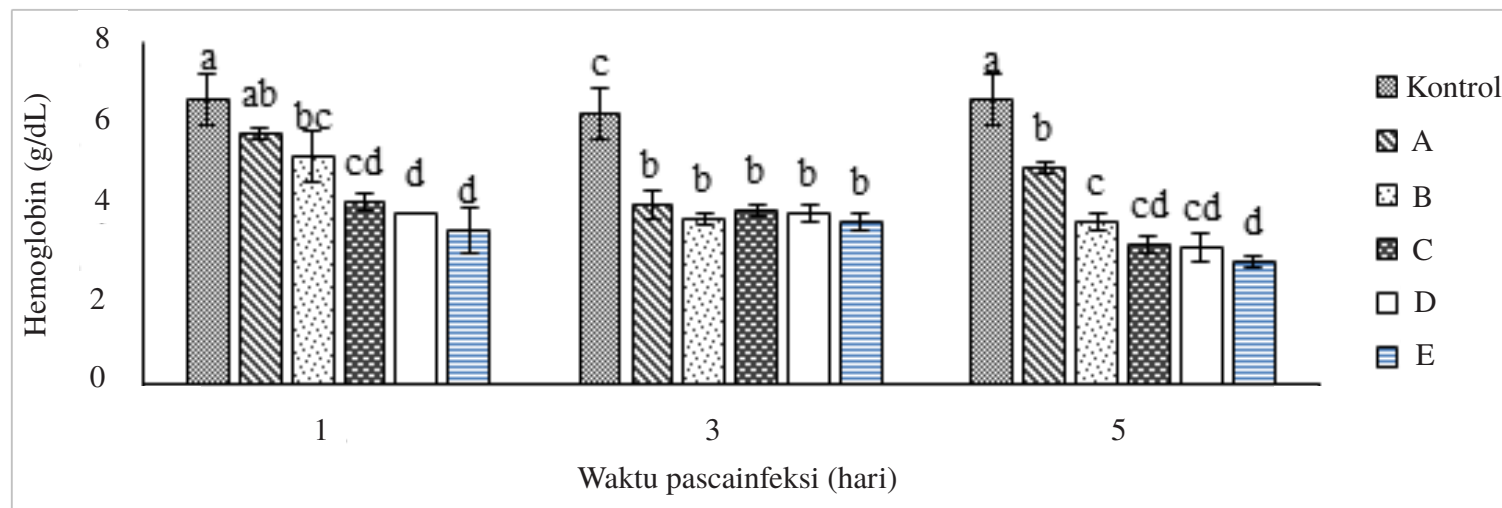

Gambar 5. Kadar hemoglobin darah ikan patin pascainfeksi E. ictaluri dengan konsentrasi berbeda. Kontrol, (A) konsentrasi $10^{2} \mathrm{cfu} / \mathrm{mL}$, (B) konsentrasi $10^{4} \mathrm{cfu} / \mathrm{mL}$, (C) konsentrasi $10^{6} \mathrm{cfu} / \mathrm{mL}$, (D) konsentrasi $10^{8} \mathrm{cfu} / \mathrm{mL}$, (E) konsentrasi $10^{10} \mathrm{cfu} / \mathrm{mL}$. Huruf yang berbeda menunjukkan nilai berbeda nyata $(\mathrm{P}<0,05)$.

Tabel 4. Jumlah kematian ikan patin (n=30) setelah diinfeksi E. ictaluri

\begin{tabular}{ccccccccccc}
\hline \multirow{2}{*}{$\begin{array}{c}\text { Konsentrasi bakteri } \\
\text { (cfu/mL) per ikan }\end{array}$} & $\begin{array}{c}\text { Jumlah ikan } \\
\text { (ekor) }\end{array}$ & 1 & 2 & 3 & 4 & 5 & 6 & 7 & Total mati \\
\cline { 3 - 8 } (ekor)
\end{tabular}


Tabel 5. Perhitungan LD50 E. ictaluri yang diinfeksi pada ikan patin

\begin{tabular}{cccccccc}
\hline $\begin{array}{c}\text { Konsentrasi bakteri } \\
\text { (cfu/mL) per ikan }\end{array}$ & Log konsentrasi & $\mathrm{R}$ & $\mathrm{N}-\mathrm{R}$ & $\sum \mathrm{R}$ & $\sum(\mathrm{N}-\mathrm{R})$ & Total & Persentase mortalitas \\
\hline Kontrol & 0 & 0 & 30 & 0 & 81 & 81 & $0,00 \%$ \\
$10^{2}$ & 2 & 4 & 26 & 4 & 51 & 55 & $7,27 \%$ \\
$10^{4}$ & 4 & 13 & 17 & 17 & 25 & 42 & $40,48 \%$ \\
$10^{6}$ & 6 & 22 & 8 & 39 & 8 & 47 & $82,98 \%$ \\
$10^{8}$ & 8 & 30 & 0 & 69 & 0 & 69 & $100,00 \%$ \\
$10^{10}$ & 10 & 30 & 0 & 99 & 0 & 99 & $100,00 \%$ \\
\hline
\end{tabular}

Keterangan : selang proporsi $=0,224 ; \operatorname{LD} 50=\operatorname{antilog}\{4+(0,224 \times 2)\}=\operatorname{antilog} 4,448=2,8 \times 10^{4} \mathrm{cfu} / \mathrm{mL} ; \mathrm{N}=$ jumlah ikan uji setiap perlakuan $=30$ ekor; $\mathrm{R}=$ jumlah ikan yang mati setiap perlakuan (ekor); $*=$ kematian $<50 \%$; $* *=$ kematian $>50 \%$.

oleh Dong et al. (2015), infeksi E. ictaluri dengan konsentrasi $2,6 \times 10^{6} \mathrm{sel} / \mathrm{mL}$ menyebabkan kematian sampai $80 \%$ pada ikan patin $P$. hypophthalmus. Hal ini membuktikan bahwa $E$. ictaluri bersifat sangat patogen terhadap ikan patin karena infeksi kepadatan yang rendah telah menyebabkan tingginya mortalitas dan ikan patin $P$. hypophthalmus merupakan salah satu inang definitif bagi bakteri E. ictaluri.

\section{KESIMPULAN}

Edwardsiella ictaluri isolat lokal bersifat sangat patogen pada ikan patin Pangasionodon hypophthalmus dengan menimbulkan kerusakan jaringan pada organ hati, ginjal, dan otak serta menyebabkan ikan mengalami anemia karena menurunnya nilai hematokrit dan hemoglobin. Konsentrasi infeksi yang dapat menyebabkan kematian $50 \%$ pada ikan patin adalah $2,8 \times 10^{4}$ $\mathrm{cfu} / \mathrm{mL}$.

\section{DAFTAR PUSTAKA}

[BBAT] Balai Budidaya Air Tawar Mandiangin. 2013. Laporan Evaluasi Monitoring Kesehatan Ikan dan Lingkungan Tahun 2012. Banjar: Balai Budidaya Air Tawar Mandiangin.

Booth NJ, Elkamel A, Thune RI. 2006. Intracellular replication of Edwardsiella ictaluri in Channel catfish macrophages. Journal of Aquatic Health 18: 101-108.

Cheville NF. 2006. Introduction to veterinary pathology. $3^{\text {th }}$ ed. Ames Lowa USA: Black well publishing. Hlm. 370.

Cunningham FL, Jack SW, Hardin D, Wills RW. 2014. Risk factors associated with enteric septicemia of catfish on mississippi commercial catfish farms. Journal of Aquatic
Animal Health 26: 84-90.

Docan A, Cristea V, Grecu I, Dediu L. 2010. Haematological response of the european catfish Silurus glanis reared at different densities in flow-through production system. Archiva Zootechnica 13: 63-170.

Dong HT, Nguyen VV, Phiwsaiya K, Gangnonngiw W, Withyachumnarnkui B, Rodkhum C, Senapin S. 2015. Concurrent infection of Flavobacterium columnare and Edwardsiella ictaluri in striped catfish, Pangasionodon hypopthalmus in Thailand. Aquaculture 448: 142-150.

Hassan ES, Mahmoud MM, Kawato Y, Nagai T, Kawaguchi O, Iida Y, Yuasa K, Nakai T. 2012. Subclinical Edwardsiella ictaluri infection of wild ayu Plecoglossus altivelis. Fish Pathology 47: 64-73.

Hawke JP, Kent M, Rogge M, Baumgartner W, Wiles J, Shelley J, Savolainen LC, Wagner R, Murray K, Peterson TS. 2013. Edwardsiellosis caused by Edwardsiella ictaluri in laboratory populations of zebrafish Danio rerio. Journal of Aquatic Animal Health 25: 171-183.

Hekimoglu MA, Guner Y, Yavuz S, Akcan G, Gulec F. 2014. Farming of Pangasius for sustainable aquaculture. Journal of Science and Technology 2: 47-54.

Iwanowicz LR, Griffin AR, Cartwright DD, Blazer VS. 2006. Mortality and pathology in brown bullheads Amieurus nebulosus associated with a spontaneous Edwardsiella ictaluri outbreak under tank culture conditions. Diseases of Aquatic Organisms 70: 219-225.

Kim JD and Park SW. 2015. Edwardsiella ictaluri infection in cultured yellow catfish Pelteobagrus fulvidraco fingerlings in Korea. Korean Journal Fish Aquatic Science 48: 725730. 
Koswara AD. 2009. Kajian patogenesis infeksi buatan bakteri Edwardsiella ictaluri pada ikan lele Clarias sp. [Tesis]. Bogor: Institut Pertanian Bogor.

Kumaran S, Deivasigamani B, Alagappan KM, Sakthivel M. 2010. Infection and immunization trials of asian seabass Lates calcarifer against fish pathogen Vibrio anguillarum. Journal of Environmental Biology 31: 539-541.

Nagai T, Iwamoto E, Sakai T, Arima T, Tensha K, Iida Y, Iida T, Nakai T. 2008. Characterization of Edwardsiella ictaluri isolated from wild ayu Plecoglossus altivelis in Japan. Fish Pathology 43: 158-163.

Pasnik DJ, Evans JJ, Klesius PH. 2007. Experimental Edwardsiella ictaluri infection causes mortality in white perch Morone americana. Journal of Animal and Veterinary Advances 6: 646-649.

Petrie-Hanson L, Romano CL, Mackey RB, Khosravi P, Hohn CM, Boyle CR. 2007. Evaluation of zebrafish Danio rerio as a model for enteric septicemia of catfish (ESC). Journal of Aquatic Animal Health 19: 151-158.

Saganuwan AS. 2011. A modified arithmetical method of Reed and Muench for determination of a relatively ideal median lethal dose (LD50). African Journal of Pharmacy and Pharmacology 12: 1.543-1.546

Sakai T, Kamaishi T, Sano M, Tensha K, Arima T, Iida Y, Nagai T, Nakai T, Lida T. 2008. Outbreaks of Edwardsiella ictaluri infection in ayu Plecoglossus altivelis in Japanese Rivers. Fish Pathology 43: 152-157.

Sakai T, Yuasa K, Ozaki A, Sano M, Okuda R, Nakai T, Iida T. 2009. Genotyping of Edwardsiella ictaluri isolates in Japan using amplified-fragment length polymorphism analysis. Letter in Applied Microbiology 49: 443-1449.

Shoemaker CA, Klesius PH, Arias CR, Evans JJ. 2009. Use of modified live vaccines in aquaculture. Journal of The World Aquaculture Society 40: 573-585.

Shoemaker CA, Martins ML, Xu D, Klesius PH. 2012. Effect of Ichthyophthirius multifiliis parasitism on the survival, hematology and bacterial load in Channel catfish previously exposed to Edwardsiella ictaluri. Parasitology Research 111: 2.223-2.228.

Soto E, Griffin M, Arauz M, Riofrio A, Martinez A \& Cabrejos ME. 2012. Edwardsiella ictaluri as the causative agent of mortality in cultured Nile tilapia. Journal of Aquatic Animal Health 24: 81-90.

Susanto. 2009. Pembenihan dan Pembesaran Patin. Jakarta, Indonesia: Penebar Swadaya.

Suanyuk N, Rogge M, Thune R, Watthanaphiromsakul M, Champhat N, Wiangkum W. 2014. Mortality and pathology of hybrid catfish, Clarias macrocephalus (Günther) $\times$ Clarias gariepinus (Burchell), associated with Edwardsiella ictaluri infection in southern Thailand. Journal of Fish Diseases 37: 385-395.

Thinh NH, Kuo TY, Hung LT, Loc TH, Chen SC, Evensen Q, Schuurman HJ. 2009. Combined immersion and oral vaccination of Vietnamese catffish Pangasianodon hypopthalmus confers protection against mortality caused by Edwardsiella ictaluri. Fish and Shellfish Immunology 27: 773-776.

Williams ML, Lawrence ML. 2005. Identification and characterization of a two-component hemolysin from Edwardsiella ictaluri. Veterinary Microbiology 108: 281-289. 